\title{
Restoration of productivity in tropical eroded soils under appropriate management'
}

\author{
Fernando Abruña and Miguel A. Lugo-López?
}

ABSTRACT

Data present the importance of appropriate management, including fertilization, liming and addition of organic matter sources, to restore the productive polential of eroded soils in the humid tropics. Exposure to heat and drying and wetting cycles under field conditions rapidly improved the tilth of an exposed subsoil in one of the Orthoxic Tropohumults. Pangolagrass yields strongly responded to $N, P, K$, and sometimes to Ca applieations. With proper fertilization the exposed subsoil produced $80 \%$ as much forage as the topsoil. Beneficial effects attributable to the use of filter press cake are reported. Tilling the subsoil had no effect on the rate at which pangolagrass covered the soil.

\section{INTRODUCTION}

This paper presents data from experiments designed to determine the management requirements of eroded subsoils and of Ultisols for erosion control and stable crop production under humid tropical conditions.

Large areas of land throughout the humid tropics are subject to a high degree of erosion due mostly to heavy rainfall, indiscriminate deforestation of steep slopes, and clean cultivation without adequate protection $(7,8,9,12,13,14,16)$. This mismanagement leads in extreme cases to exposure of the subsoil and even of the parent material of low inherent productivity. When these soils are continuously cultivated and poorly managed, crop yields are minimal. In many areas, this can be attributed to shifting cultivators in their search for lands to grow food crops and the quest for firewood and for wood to make charcoal. Road construction, housing developments, strip mining, construction of bench terraces, and other practices also cause excessive soil erosion. The importance of controlling erosion has been duly emphasized $(6,13)$. On the other hand, published data on the feasibility of tropical soil productivity recovery is scant, and whatever is available is usually not given the recognition it deserves. The concept prevails that eroded tropical soils are not apt to be restored to their productive potential within a reasonable time. There are also vast areas of $O x i s o l s$ and Ultisols which present similar problems to those of exposed subsoils.

${ }^{3}$ Manuscript submitted to Editorial Board July 7, 1986.

${ }^{2}$ Associate Deputy. Director and Soil Scientist (ret.), respectively, Agricultural Experiment Station, University of Puerto Rico, Río Piedras, P. R. 
Erosion control in these areas has generally been attempted by longterm rotations with forests, maintenance of soil organic matter, mulching and other agronomic practices. Soil conservation practices such as contour cultivation, strip cropping, terracing, hillside ditches and others have been widely used in some areas. It appears that massive treatment of these soils and subsoils with lime, N, P, K fertilizer and micronutrients coupled with suitable rotations with intensively managed grasses can restore soil productivity, eontrol erosion and produce crops on a stable, long-term basis.

\section{MATERIALS AND METHODS}

At the experimental site, the upper $30 \mathrm{~cm}$ of topsoil of an Alonso clay (Orthoxic Tropohumults) were completely removed with a bulldozer and the area divided into plots $15^{\prime} \times 15^{\prime}$. The topsoil was then replaced in 12 of the plots as called for in the experimental design. In addition there were 52 subsoil plots for a total of 64 plots. Three experiments were conducted concurrently with seven treatments each. In the first experiment, treatment differentials were as follows (all plots limed at the rate of $9 \mathrm{t} / \mathrm{ha}$, except when indicated):

Subsoil

Complete fertilization ${ }^{3}$

Complete fertilization except lime

Complete fertilization except $\mathrm{K}$

Complete fertilization except $\mathrm{P}$

Complete fertilization except $\mathrm{N}$

Topsoil

Unfertilized

Complete fertilization ${ }^{3}$

Once the pangolagrass was well established (18 months after planting), another set of treatment differentials (Experiment 2) was imposed in the plots whose treatments corresponded or were similar to those of Experiment $1 .^{4}$ The unfertilized topsoil treatment was replaced by an unfertilized subsoil treatment.

In the third experiment, treatments were modified to evaluate various practices to establish a new pangolagrass stand. All subsoil and topsoil plots received a complete fertilizer. Treatment differentials were as follows: 1) subsoil: no tillage; tillage; filter press cake; filter press cake + tillage; bagasse; bagasse + tillage; and 2) topsoil (tillage). All treatments were replicated four times in a randomized block design. Some of

${ }^{3}$ A total of $280 \mathrm{~kg} / \mathrm{ha}$ of $\mathrm{N}, 168$ of $\mathrm{P}, 336$ of $\mathrm{K}$ and 56 of Mg were applied. Limestone was used at the rate of $4 \mathrm{t} / \mathrm{ha}$.

4Fertilizer divided into 6 equal applications of $\mathrm{N}=560, \mathrm{P}=224, \mathrm{~K}=673$ and $\mathrm{Mg}=$ $112 \mathrm{~kg} / \mathrm{ha} / \mathrm{yr}$. 
the treatments were common to all three experiments. In those cases each plot had only one treatment throughout the study.

Soil samples were taken at four depth intervals down to $45 \mathrm{~cm}$ in four of the five replicates. Samples were air dried, crushed and sieved through a 20-mesh sieve and extracted with $\mathrm{N}$-neutral $\mathrm{NH}_{4} \mathrm{OAc}$. Non exchangeable $\mathrm{K}$ was extracted with $1 \mathrm{~N}$ hot $\mathrm{HNO}_{3}(10)$. Easily reducible $\mathrm{Mn}$ was extracted with $\mathrm{N}$-neutral $\mathrm{NH}_{4} \mathrm{OAc}$ containing $0.2 \%$ hydroquinone. Exchangeable $\mathrm{Ca}$ and $\mathrm{Mg}$ were determined by the Versenate method (5), both forms of $\mathrm{K}$ by flame photometry, both forms of $\mathrm{Mn}$ colorimetrically after oxidation to $\mathrm{KMnO}_{4}$ with $\mathrm{KIO}_{4}$. Organic carbon was determined by the wet combustion method and organic matter calculated by means of the standard factor. The $\mathrm{pH}$ was measured by glass electrode with a 1 to 1.5 soil to water ratio.

In another set of undisturbed $10-\mathrm{cm}$ high by $10-\mathrm{cm}$ diameter core samples such physical properties as volume weight, pores drained at $1 / 3$ bar and percolation rates after saturation, were determined.

Pangolagrass (Digitaria decumbens Stant.) was planted in all plots in furrows $0.8 \mathrm{~m}$ apart with stem cuttings as planting material. Yields were determined by cutting all plots every 60 days once the grass had covered the soil. Dry matter yields were determined after the forage samples were dried to constant weight at $70^{\circ} \mathrm{C}$ in a forced-air drying cabinet.

\section{RESULTS AND DISCUSSION}

Table 1 shows that the original soil, as sampled in a fairly virgin site, was very high in organic matter in the upper $7 \mathrm{~cm}$, and low in exchangeable $\mathrm{Ca}$ and $\mathrm{Mg}$. Both exchangeable and non-exchangeable $\mathrm{K}$ contents were medium-high. The soil in the upper $7 \mathrm{~cm}$ showed a high exchange capacity as determined by the $\mathrm{NH}_{4} \mathrm{OAc}$ method, but the base saturation was extremely low. Most of the exchange sites appear to be in the organic matter since exchange capacity in subsoils was considerably lower than in organic matter-rich topsoil. Organic matter, exchangeable bases and even non-exchangeable $\mathrm{K}$ were very low throughout the whole profile of the experimental area, although fairly constant. Exchangeable and easily reducible $\mathrm{Mn}$ were very high throughout the profile of the non-eroded soil site. However, they were fairly low throughout the exposed subsoil. These differences in $\mathrm{Mn}$ content are likely to be associated with the extreme variations in the organic matter content of the soil at the experimental area and where the original soil was sampled.

Table 2 shows that although the exposed subsoil and lower soil layers have good and fairly uniform physical characteristics, the whole profile of the unaltered original soil was far better in these respects. This is evident by bulk densities (1.13 vs. .98) and saturated percolation rates (14 vs. $225 \mathrm{~mm} / \mathrm{hr}$ ) variations. 
TABLE 1.-Chemical properties of the original Alonso clay soil and the exposed subsoil at the experimental site

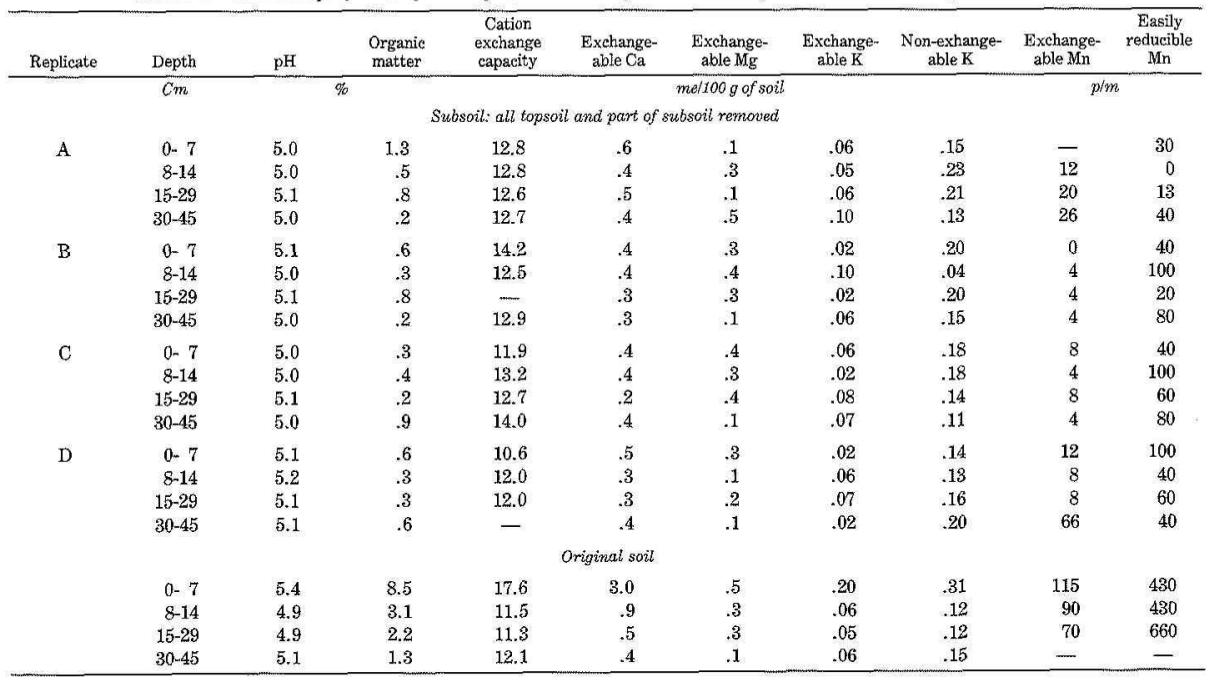


TABLE 2.-Physical condition of the soil and subsoit at the beginning of the enperiment to determine the management requirements of an exposed Alonso clay subsoil

\begin{tabular}{|c|c|c|c|c|}
\hline $\begin{array}{l}\text { Replieate } \\
\text { or sample } \\
\text { number }\end{array}$ & Plot No. & Density & $\begin{array}{l}\text { Pores drained at } \\
1 / 3 \text { atmosphere } \\
\text { of pressure }\end{array}$ & $\begin{array}{c}\text { Saturated } \\
\text { pereolation } \\
\text { rate }\end{array}$ \\
\hline & & glome & $\%$ & In/hr \\
\hline \multicolumn{5}{|c|}{ Subsoil (All topsoil and part of subsoil removed) } \\
\hline A & $\begin{array}{l}14 \\
15 \\
16\end{array}$ & $\begin{array}{l}1.15 \\
1.20 \\
1.24\end{array}$ & $\begin{array}{l}5.9 \\
7.8 \\
6.9\end{array}$ & $\begin{array}{r}.6 \\
1.1 \\
.1\end{array}$ \\
\hline B & $\begin{array}{l}14 \\
15 \\
16\end{array}$ & $\begin{array}{l}1.19 \\
1.16 \\
1.17\end{array}$ & $\begin{array}{l}5.5 \\
8.7 \\
4.9\end{array}$ & $\begin{array}{r}1.4 \\
1.3 \\
.1\end{array}$ \\
\hline C & $\begin{array}{l}14 \\
15 \\
16\end{array}$ & $\begin{array}{l}1.18 \\
1.30 \\
1.22\end{array}$ & $\begin{array}{r}11.2 \\
7.8 \\
5.1\end{array}$ & $\begin{array}{r}.1 \\
1.1 \\
.1\end{array}$ \\
\hline D & $\begin{array}{l}14 \\
15 \\
16\end{array}$ & $\begin{array}{l}1.18 \\
1.02 \\
1.23\end{array}$ & $\begin{array}{c}12.7 \\
- \\
10.5\end{array}$ & $\begin{array}{l}.1 \\
- \\
-\end{array}$ \\
\hline \multicolumn{5}{|l|}{ Mean, } \\
\hline & & Original so & & \\
\hline Sample No. & $\begin{array}{l}1 \\
2 \\
3 \\
4 \\
5 \\
6\end{array}$ & $\begin{array}{r}.90 \\
1.00 \\
1.01 \\
.92 \\
1.05 \\
1.00\end{array}$ & $\begin{array}{l}13.2 \\
14.4 \\
11.2 \\
11.5 \\
13.8 \\
17.5\end{array}$ & $\begin{array}{r}10 \\
10 \\
10 \\
3.0 \\
4.2 \\
10\end{array}$ \\
\hline $\begin{array}{l}\text { Mean, } \\
\text { Topsoil }\end{array}$ & & .98 & 13.6 & 10 \\
\hline
\end{tabular}

In this connection it is interesting to note that weathering rapidly altered the structure of the exposed subsoil which had been somewhat compacted by the bulldozer. Two months after exposure to heat and to wetting and drying cycles the upper two inches of soil had attained an excellent crumb structure with high permeability to water. This resulted in a good seedbed, but erosion losses during downpours were greater since water penetrating the surface soil and then encountering the less permeable subsoil moved downhill carrying large quantities of the loose surface soil with it.

Pangolagrass took over a year to get established in the exposed subsoil because heavy rains during the first year repeatedly worked away the loose crumbly top $10 \mathrm{~cm}$ overlying a less permeable soil layer. The following tabulation shows the effect of variable fertilization on dry matter yields produced by pangolagrass 2 months after the grass was well established: 


\section{Treatment}

Subsoil + complete fertilization ${ }^{3}$

Subsoil + complete fertilization except lime

Subsoil + complete fertilization except $\mathrm{K}$

Subsoil + complete fertilization except $\mathrm{P}$

Subsoil + complete fertilization except $\mathrm{N}$

Topsoil, unfertilized

Topsoil + complete fertilization ${ }^{3}$
Yields of dry $\frac{\text { pangolagrass forage }}{(\mathrm{kg} / \mathrm{ha})}$

4,315

4,425

1,895

895

290

1,645

5,155

These data show that pangolagrass growing in an Alonso subsoil responded very strongly to applications of $\mathrm{N}, \mathrm{P}$ and $\mathrm{K}$, but did not respond to liming at this stage of growth. The fertilized subsoil yielded almost as much forage as the fertilized topsoil, while the unfertilized topsoil produced yields as low as those of the subsoil without $K$ fertilization. It appears that the original soil was almost depleted of nutrients with the probable exception of $\mathrm{N}$ resulting from the decomposition of organic matter and some residual $\mathrm{P}$ from previous fertilizations.

Once the grass was well established (18 months after planting), a second experiment was done in the plots with treatments similar to those in experiment 1. Table 3 shows that Pangola responded strongly to applications of $N, P, K$ and lime when all other nutrients were provided in abundance. It is noteworthy that with proper fertilization the subsoil produced about $80 \%$ of the maximum yield obtained in the topsoil with complete fertilization.

In the third experiment various practices for establishing pangola grass stands were compared in terms of percentage of ground cover and green forage yield produced by pangolagrass. Table 4 shows that tilling:

TABLE 3,-Response to fertilization of Pangola grass growing on an Alonso subsoil over a one year period after 30 months since being planted

\begin{tabular}{lrr}
\hline & \multicolumn{2}{c}{ Yield data (kg/la) } \\
\cline { 2 - 3 } Treatinent & Green matter & Dry matter \\
\hline Subsoil with no fertilization & 1,870 & 500 \\
Subsoil with complete fertilization & 98,400 & 24,600 \\
Subsoil with fertilization except lime & 72,700 & 18,170 \\
Subsoil with fertilization except $\mathrm{K}$ & 10,600 & 2,760 \\
Subsoil with fertilization except $\mathbf{P}$ & 20,000 & 5,200 \\
Subsoil with fertilization except $\mathbb{N}$ & 4,120 & 1,100 \\
Topsoil with complete fertilization & 120,000 & 28,800 \\
LSD 5\% & & 1,359 \\
$1 \%$ & & 1,506 \\
\hline
\end{tabular}

$\mathrm{Kg} / \mathrm{ha}$ yearly divided in 6 equal applications: $\mathrm{N}=660, \mathrm{P}=224, \mathrm{~K}=673$, and $\mathrm{Mg}=112$.

Limestone 18 tha only initially. 
TABLE 4.-Effect of fertilizer, organie matter sources and tillage on pangolagrass yields on an exposed subsoil

\begin{tabular}{lcc}
\hline \multicolumn{1}{c}{ Treatment } & $\begin{array}{c}\text { Ground cover } \\
60 \text { days after } \\
\text { planting }\end{array}$ & $\begin{array}{c}\text { Yields of } \\
\text { green forage } \\
\text { 120 days after } \\
\text { planting }\end{array}$ \\
\hline Subsoil + fertilizer & $\%$ & $\mathrm{~kg} / \mathrm{ha}$ \\
Subsoil + fertilizer, tillage & 74 & 15,995 \\
Subsoil + fertilizer + filter press calke, no tillage & 53 & 14,800 \\
Subsoil + fertilizer + filter press cake, tillage & 91 & 18,460 \\
Subsoil + fertilizer + bagasse, no tillage & 78 & 14,720 \\
Subsoil + fertilizer + bagasse, tillage & 81 & 15,530 \\
Topsoil + fertilizer, tillage & 79 & 18,325 \\
L.S.D. $5 \%$ & 96 & 18,990 \\
$1 \%$ & 8.6 & $\mathrm{~N} . \mathrm{S}$. \\
\hline
\end{tabular}

the soil before planting had no additional beneficial effect on the rate at which Pangola grass covered the soil whether in combination with complete fertilizer alone or with fertilizer in addition to bagasse or filter press cake. Filter press cake at a rate of $18 \mathrm{t} / \mathrm{h}$ (dry weight basis) in addition to fertilizer accelerated, but bagasse had no effect on the rate at which pangolagrass covered the soil. The green forage yields 4 months after planting were not affected by treatments. The following tabulation shows the nutrient contents of the applied filter press cake:

$\begin{array}{cc}\text { Nutrient } & \text { Content-kg/t } \\ \mathrm{N} & 43 \\ \mathrm{P} & 32 \\ \mathrm{~K} & 12 \\ \mathrm{Ca} & 196 \\ \mathrm{Mg} & 49\end{array}$

Although the nutrient contribution of filter press cake was sizeable, the fertilized subsoil plot received more than sufficient nutrients for adequate grass growth. The beneficial effects of filter press cake might be attributed to its effect on moisture retention and cooler temperatures promoted in the upper soil layer. The beneficial effect of minor elements or the microbial activity, or both, provided by the filter press cake could be contributing factors.

Excellent yields of forage were produced only a few months after planting in the plots where topsoil had been replaced (table 4). Fertilization of the topsoil had little effect on yields during the first cutting but the grass responded increasingly over subsequent cuttings and yields were about tripled by fertilization over the last harvest period. 
Table 5 shows that over the last harvest period, yields produced by the fertilized topsoil were very similar to those produced by the similarly fertilized subsoil on which pangolagrass was established with the help of filter press cake applications. During this period the unfertilized topsoil produced less than half as much forage as the fertilized subsoil. On the other hand, the unfertilized topsoil showed a steady decrease in yield with age, but even at 21 months yields were similar to those produced by the heavy fertilized subsoil without filter press cake, whereas the heavily fertilized subsoil plus filter cake produced yields comparable to those of the heavily fertilized topsoil. The fact that the heavily fertilized topsoil to which filter press cake was previously applied yielded twice as much as the heavily fertilized subsoil (without filter press cake) indicates that the beneficial effect of filter press cake could be attributed to something more than the effect on temperature and moisture retention. The chelating effect of the organic fraction of filter press cake on toxic substances in the soil, the steady supply of minor elements, the retention of nutrients against leaching and runoff as well as better developed root systems might be contributing factors.

Table 6 summarizes data obtained from other field experiments by Abruña et al. (1, 2, 3, 4), Vicente-Chandler et al. (16) and Rivera et al. $(10,11)$ as to crop response to soil acidity factors in an eroded (topsoil removed) and non-eroded Ultisol of Puerto Rico. It is evident from these data that given the use of high-yielding cultivars and adequate crop protection schemes, high production levels can be attained in eroded soils if lime and fertilizers are judiciously used under intensive management systems.

TABLE 5.-The effect of fertilization and filter press cake application on growth of Pangola planted on an antilled Alonso clay and subsoil near Adjuntas. Data herein reported were obtained at 10-, 15-, 17- and 21 months after planting. All values are averages of four replications

\begin{tabular}{|c|c|c|c|c|c|}
\hline \multirow[b]{2}{*}{$\begin{array}{c}\text { Age of } \\
\text { harvest }\end{array}$} & \multicolumn{5}{|c|}{ Yíelds of dry Pangola grass (kg/ha) } \\
\hline & $\begin{array}{c}\text { Subsoil } \\
\text { without } \\
\text { ferti- } \\
\text { lization }\end{array}$ & $\begin{array}{l}\text { Subsoil } \\
\text { with } \\
\text { heavy } \\
\text { fertili- } \\
\text { zation }\end{array}$ & $\begin{array}{l}\text { Subsoil with } \\
\text { heavy ferti- } \\
\text { lization and } \\
\text { fitter press } \\
\text { cake applica- } \\
\text { tion }^{2}\end{array}$ & $\begin{array}{l}\text { Topsoil } \\
\text { without } \\
\text { fertili- } \\
\text { zation }\end{array}$ & $\begin{array}{c}\text { Topsoil } \\
\text { with } \\
\text { heavy } \\
\text { fertil- } \\
\text { zation1 }\end{array}$ \\
\hline \multicolumn{6}{|l|}{ Months } \\
\hline 10 & 0 & 0 & 2,125 & 5,630 & 5,800 \\
\hline 15 & 0 & 0 & 4,450 & 3,400 & 5,160 \\
\hline 17 & 64 & 515 & 4,040 & 4,000 & 5,940 \\
\hline 21 & 0 & 3,000 & 5,600 & 2,245 & 6,930 \\
\hline
\end{tabular}

' A total of $112 \mathrm{~kg} \mathrm{P}$ (from $20 \%$ superphosphate), $224 \mathrm{~kg} \mathrm{~K}$ (from KCl), 9 tons limestone and $45 \mathrm{~kg} \mathrm{Mg}$ (from $\mathrm{MgSO}_{4}$ ) per hectare.

${ }^{2} 36$ tons per hectare applied at planting time and again after 12 months. 
TABLE 6.-Yields of various crops in non-eroded and eroded (topsoil removed) Corozal clay (Aquic Tropudults)

\begin{tabular}{|c|c|c|c|}
\hline \multirow[b]{2}{*}{ Crop } & \multirow[b]{2}{*}{ Unit } & \multicolumn{2}{|c|}{ Yields in indicated soil ${ }^{1}$} \\
\hline & & Non-eroded & Eroded \\
\hline Sweetpotato & tha & 13.8 & 11.5 \\
\hline Taniens & tha & 16.3 & 16.0 \\
\hline Cassava & tha & 26.5 & 28.7 \\
\hline Maize & bu/acre & 66.5 & 56.9 \\
\hline Soybeans & $\mathrm{kg} / \mathrm{ha}$ & 2081 & 2474 \\
\hline Cabbuge & $\mathrm{kg} / \mathrm{ha}$ & 11,440 & 18,510 \\
\hline Green beans & lbs/acre & 9,970 & 10,450 \\
\hline
\end{tabular}

${ }^{1}$ High-yielding cultivars, adequate crop protection, liming and fertilization were used in a complete package of technological practices.

An overall examination of the available data reveals that fertilization and liming are the key factors in restoring productivity of an exposed subsoil of a typical Ultisol of the humid tropics. In fact, when dealing with extremely acid Ultisols with high concentrations of exchangeable $\mathrm{Al}$, liming is as or even more important than fertilization.

The red acid deep Ultisols as well as the Oxisols of the tropics are almost depleted of plant nutrients, but posses excellent physical conditions. Moreover, their chemical and physical characteristics are quite uniform throughout the whole profile. Therefore, a severely eroded Ultisol or Oxisol differs from a normal profile in its organic matter content only if it has not been rested for a long period of time. It is evident that when these eroded soils are provided with nutrients and possibly organic matter, their production potential might be restored to near maximum levels.

The purpose of the paper is not to undermine the prevailing concept that soil erosion is a serious problem in the tropics. It is rather to emphasize the importance of appropriate management as a means of realizing the potential productivity of these soils even when devoid of a generally rich topsoil of favorable structure.

\section{RESUMEN}

\section{Restauración de la productividad a los suelos tropicales erosionados atendiéndolos adecuadamente}

Se presentan datos que destacan la importancia del uso de prácticas adecuadas de manejo de suelos, incluyendo fertilización, encalado y fuentes de materia orgánica, para restaurar la productividad de suelos erosionados de los trópicos húmedos. La exposición al calor y a ciclos de humedecimiento y secado, en condiciones de campo, mejoraron rápidamente las propiedades físicas de un subsuelo expuesto en uno de los Orthoxic Tropohumulis. La yerba Pangola respondió marcadamente en términos de rendimiento de forraje a las aplicaciones de N, P, K y en algunos casos a las de Ca. Cuando 
el subsuelo expuesto se abonó adecuadamente se obtuvo un nivel de $80 \%$ de la producción obtenida en el suelo donde no se expuso el subsuelo. Se observaron efectos beneficiosos que se pueden atribuir a la aplicación de cachaza. La labranza del subsuelo no influyó en la rapidez con la que la yerba Pangola cubrió el suelo.

\section{LITERATURE CITED}

1. Abruña-Rodrígulez, F., R. Pérez-Escolar, J. Vicente-Chandler, J. Figarella and S. Silva, 1974. Response of green beans to acidity factors in tropical soils, J. Agric. Univ. P. R. 58 (1); 4458.

2. Abruña, F., R. Pérez-Escolar, J. Vicente-Chandler, R. W. Pearson and S. Silva, 1974. Response of com to aeidity factors in eight tropical soils, J. Agric. Univ. P. R. 58 (1): $59-77$.

3. Abruna, F., J. Rodríguez, J. Badillo-Feliciano, S. Silva and J. Vicente-Chandler, 1978. Crop response to soil acidity factors in Ultisols and Oxisols in Puerto Rieo-Soybeans, J. Agric. Univ. P. R. 62 (1): 90-112.

4. Abruña, F., J. Vicente-Chandler, J. Rodrfguez, J. Badillo and S. Silva, 1979. Crop response to soil acidity factors in Ultisols and Oxisols in Puerto Rico. V. Sweet potato, J. Agrie. Univ. P. R. 63 (3): 250-67.

5. Cheng, K. L. and R. H. Bray, 1951. Determination of calcium and magnesium in soil and plant materials. Soil Sci. 72: 499-58.

6. Lugo-López, M. A., F. Abruña and R. Pérez-Escolar, 1981. The role of crop and industrial residues in erosion control, properties and productivity of some major soils of Puerto Rico, Univ. P. R. Agric. Exp. Stn. Buli, 266.

7. Lugo-López, M. A, and G. Acevedo, 1982. K values of the solls of Puerto Rico, J. Agric. Univ. P. R. 66 (4): 311-12.

8. Lugo-López, M. A. and J. Villarrubia-Cruz, 1985. Conflict in land-use in the Puriscal area of the Río Parrita Watershed in southwestern Costa Rica, J. Agric. Univ. P. R. 69 (3): $451-53$.

9. Pratt, P. F., 1965. Potassium in C. A. Black (Ed) Methods of soil analysis, part 2. Agronomy 9: 1022-030.

10. Rivera, F., F. Abruña and J. Rodriguez, 1981. Crop response to soil acidity factors in Ultisols and Oxisols in Puerto Rico. XI. Cassava, J. Agric. Univ. P. R. 69 (2): 145-51.

11. Rivera, E., J. Rodríguez and F. Abruña, 1985. Crop response to soil acidity factors in Ultisols and Oxisols in Puerto Rico. XIII. Cabbage, J. Agric. Univ. P. R. 69 (3): 367-76.

12. Reynolds, C. A., A. Wahab and M. A. Lugo-Lopez, 1985. K values of the soils of the Acul Watershed in Haiti, J. Agric. Univ. P. R. 69 (3): 441-43.

13. Smith, R. M. and F. Abruña, 1985. Soil and water conservation research in Puerto Rico, 1938 to 1947, Univ. P. R. Agric. Exp. Stn. Bull. 124.

14. Wahab, A. H., M. A. Lugo-Lopez, B. M. Woo, E. Rosales and J. Dehaney, 1985. Alternatives to bench terraces on the hillsicles of Jamaica. 1. Soil losses, J. Agric. Univ. P. R. 69 (3); 25564.

15. Wahab, A. H., A. M. Lugo-López and G. Acevedo, 1987. Observations on soil erosion in southwestem Haiti, J. Agric. Univ. P. R. 71 (1): 00-00.

16. Vicente-Chandler, J., F. Abruna, J. Badillo-Feliciano and J. A. Rodríguez-Gareíu, 1983. The effect of soil acidity factors on crop yields. IX. Taniers, J. Agric. Univ. P. R. 67 (4): $446-52$. 